\title{
Kepastian Hukum Pengaturan Penggunaan Tenaga Kerja Asing di Indonesia
}

\author{
Risky Vista Puspita Sari \\ University of Jember, Indonesia \\ riskyvistha@gmail.com
}

\section{Aries Harianto}

University of Jember, Indonesia

dr.aries99@gmail.com

\section{Ida Bagus Oka Ana}

University of Jember, Indonesia

okaanafh@gmail.com

\begin{abstract}
The 1945 Constitution of the Republic of Indonesia states that every citizen has the right to work and a decent life. Consequently, citizens have the right to receive rewards and fair treatment in employment relations and the state has a constitutional responsibility to guarantee the fulfillment of the right to work of migrant workers and foreign workers to create protection and legal certainty between them. Meanwhile, the national labor law and government regulations regulate foreign workers including only professional workers. In fact, foreign workers working in Indonesia are not only professional workers but also unskilled laborers. This is due to the enactment of changes to the regulation of the use of foreign labor which frees and tightens foreign workers who work in Indonesia.
\end{abstract}

KEYWORDS: Foreign Workers, Supervision, Legal Certainty of Foreign Workers.

Copyright $\odot 2018$ by Author(s)

This work is licensed under a Creative Commons Attribution-ShareAlike 4.0 International License. All writings published in this journal are personal views of the authors and do not represent the views of this journal and the author's affiliated institutions.

\section{HOW TO CITE:}

Sari, Risky Vista Puspita, Aries Harianto \& Ida Bagus Oka Ana. "Kepastian Hukum Pengaturan Penggunaan Tenaga Kerja Asing di Indonesia" (2018) 5:3 Lentera Hukum 389-402.

Submitted: January 31, 2018 Revised: June 29, 2018 Accepted: December 22, 2018 


\section{PENDAHULUAN}

Istilah tenaga kerja asing (TKA) sudah menjadi fenomena yang lumrah. Dilihat dari perkembangannya, latar belakang digunakannya tenaga kerja asing di Indonesia mengalami perubahan sesuai zamannya. Ketika Belanda membuka perkebunan besar di beberapa daerah di Indonesia, seperti Sumatera Timur, alasan kelangkaan sumber daya manusia sebagai pekerja/buruh yang mendorong pemerintah Belanda ketika itu mendatangkan IPTEK, maka alasan kebutuhan menjadi alasan utama digunakan tenaga kerja asing (TKA). Menurut Budiono, ada beberapa tujuan penempatan TKA di Indonesia. Pertama, memenuhi kebutuhan tenaga kerja terampil dan profesional pada bidang-bidang tertentu yang belum dapat diisi oleh TKI; kedua, mempercepat proses pembangunan nasional dengan jalan mempercepat proses alih teknologi atau alih ilmu pengetahuan terutama di bidang industri; ketiga, memberikan perluasan kesempatan kerja bagi TKI; keempat, meningkatkan investasi asing sebagai penunjang modal pembangunan di Indonesia. ${ }^{1}$

Dari sini penggunaan tenaga kerja asing bertujuan untuk memenuhi kebutuhan tenaga kerja yang terampil dan profesional pada bidang-bidang tertentu yang mana belum dapat diduduki oleh tenaga kerja lokal serta sebagai tahapan dalam mempercepat proses pembangunan nasional ataupun daerah dengan cara mempercepat alih ilmu pengetahuan dan teknologi dan juga meningkatkan investasi asing terhadap kehadiran tenaga kerja asing dimana sebagai penunjang pembangunan di Indonesia walaupun pada faktanya perusahaan-perusahaan swasta asing maupun swasta nasional wajib menggunakan tenaga ahli bangsa Indonesia sendiri. ${ }^{2}$.Adanya pembatasan penggunaan tenaga kerja asing di Indonesia ini salah satunya adalah untuk perlindungan bagi tenaga kerja lokal sebagaimana tertuang pada Pasal 27 ayat (2) Undang-Undang Dasar Republik Indonesia 1945 yakni: “Tiap-tiap warga negara berhak atas pekerjaan dan penghidupan yang layak bagi kemanusiaan”. Negara mempunyai kewajiban supaya penetapan Undang-Undang Dasar Negara Republik Indonesia 1945 Pasal 27 ayat (2) itu dilaksanakan. ${ }^{3}$ Pada Pasal 27 ayat (2) Undang-Undang Dasar Negara Republik Indonesia 1945 lebih menekankan hak tiap warga negara dan sekaligus menentukan tugas pemerintah untuk melaksanakan kewajibannya tersebut. ${ }^{4}$

Undang-Undang Nomor 13 tahun 2003 tentang Ketenagakerjaan yang didalamnya mengatur mengenai penggunaan tenaga kerja asing, dengan adanya peraturan tersebut akan memberikan suatu kepastian hukum ataupun kejelasan norma dalam melakukan hubungan kerja. Pada Pasal 42 sampai Pasal 49 mengatur tentang penggunaan tenaga kerja asing.

Pasal 42 menyebutkan, pertama, setiap pemberi kerja yang mempekerjakan tenaga kerja asing wajib melakukan izin tertulis dari Menteri atau pejabat yang di tunjuk; kedua, pemberi kerja perseorangan dilarang mempekerjakan tenaga kerja asing; ketiga,

\footnotetext{
Budiono, dkk, 1995, Hukum Perburuhan Di Indonesia, Jakarta, PT.Rajagrafindo Persada, hlm. 115.

HR Abdussalam, 2008, Hukum Ketenagakerjaan, Jakarta: Restu agung, hlm. 322.

H.S Syarif, 1996, Pedoman Penggunaan tenaga kerja asing di Indonesia, Jakarta: Sinar Grafika, hlm. l.

Ibid.
} 
kewajiban memiliki izin sebagaimana dimaksud dalam ayat (1), tidak berlaku bagi perwakilan negara asing yang mempergunakan tenaga kerja asing sebagai pegawai diplomatik dan konsuler; keempat, tenaga kerja asing dapat dipekerjakan di Indonesia hanya dalam hubungan kerja untuk jabatan tertentu dan waktu tertentu; kelima,ketentuan mengenai jabatan tertentu dan waktu tertentu sebagaimana dimaksud dalam ayat (4) ditetapkan oleh keputusan menteri; keenam, tenaga kerja asing sebagaimana dimaksud dalam ayat (4) yang masa kerjanya habis dan tidak dapat diperpanjang dapat digantikan oleh tenaga kerja asing lainnya.

Jadi dalam Pasal 42 menegaskan bahwa pemberi kerja ketika mempekerjakan tenaga kerja asing harus memiliki izin tertulis dari menteri yang menyelenggarakan urusan pemerintahan di bidang ketenagakerjaan akan tetapi memiliki izin tertulis tersebut tidak berlaku bagi semua penggunaan tenaga kerja asing artinya ketika perwakilan negara asing dalam hal menggunakan tenaga kerja asing sebagai pegawai diplomatik dan konsuler tidak diberikan kewajiban untuk memiliki izin tertulis sebagaimana dimaksud pada ayat (l) kemudian pemberi kerja perseorangan dilarang mempekerjakan tenaga kerja asing. Tenaga kerja asing yang dipekerjakan di Indonesia hanya hubungan kerja dan waktu tertentu maksudnya adalah Pasal 1 angka 15 UndangUndang Nomor 13 Tahun 2003 tentang Ketenagakerjaan menyatakan bahwa "Hubungan kerja adalah hubungan antara pengusaha dengan pekerja/buruh berdasarkan perjanjian kerja yang mempunyai unsur pekerjaan, upah, dan perintah".

Hubungan kerja tersebut ada 3 unsur/faktor yang menentukan adanya hubungan kerja, yaitu: adanya pekerjaan yang harus dilakukan, adanya perintah (bekerja atas perintah atasan/pengusaha); dan adanya upah oleh karenanya tenaga kerja asing di Indonesia harus ada dalam hubungan kerja sebab tanpa adanya salah satu unsur dari ketiga unsur tersebut maka tidak ada hubungan kerja. ${ }^{5}$ Semetara untuk perjanjian kerja waktu tertentu tidak berlaku untuk pekerjaan yang tetap, kemudian harus dibuat dalam bentuk tulisan, jangka waktu pkwt maksimum 2 tahun, dengan satu kali perpanjangan paing lama 1 tahun, perjanjian kerja waktu tertentu (PKWT) dapat diperbaiki sebanyak satu kali selama 2 tahun dengan masa jeda 1 bulan jadi hubungan kerja untuk jabatan tertentu dan waktu tertentu. Apabila masa kerjanya telah selesai maka tenaga kerja asing tidak dapat diperpanjang kemudian dapat digantikan oleh tenaga kerja asing lainnya. Kemudian pemberi kerja dalam mempekerjakan tenaga kerja asing di Indonesia harus memperhatikan pada Pasal 43 yang telah menegaskan, pertama, pemberi kerja yang menggunakan tenaga kerja asing harus memiliki rencana penggunaan tenaga kerja asing yang disahkan oleh menteri atau pejabat yang ditunjuk; kedua, Rencana penggunaan tenaga kerja asing sebagaimana dimaksud dalam ayat (1) sekurang-kurangnya memuat alasan penggunaan tenaga kerja asing, jabatan dan/atau kedudukan tenaga kerja asing dalam struktur organisasi perusahaan yang bersangkutan, jangka waktu penggunaan tenaga kerja asing, dan penunjukkan tenaga kerja warga negara Indonesia sebagai pendamping tenaga kerja asing yang

Aries Harianto, 2016, Hukum Ketenagakerjaan Makna Kesusilaan dalam Perjanjian Kerja Yogyakata: Lakbang PRESSindo, hlm. 194. 
dipekerjakan; ketiga, ketentuan sebagaimana dimaksud dalam ayat (1) tidak berlaku bagi instansi pemerintah, badan-badan internasional dan perwakilan negara asing; keempat Ketentuan mengenai tata cara pengesahan rencana penggunaan tenaga kerja asing diatur dalam keputusan menteri.

Pengertian rencana penggunaan tenaga kerja asing (RPTKA) merupakan dokumen awal yang harus disiapkan pemberi kerja, yang berisi rencana penggunaan tenaga kerja asing (TKA) pada jabatan tertentu untuk jangka waktu tententu dan harus mendapat pengesahan dari menteri atau pejabat yang di tunjuk. Rencana penggunaan tenaga kerja asing (RPTKA) ini berguna sebagai dasar untuk mendapatkan izin mempekerjakan tenaga kerja asing (IMTA). Kewajiban membuat rencana penggunaan tenaga kerja asing (RPTKA) bagi pemberi kerja yang akan mempekerjakan tenaga kerja asing (TKA) dikecualikan khusus untuk pemberi kerja berupa instansi pemerintah, badan-badan internasional dan perwakilan negara asing. Diatur lebih lanjut pada peraturan pelaksana pada Peraturan Menteri Ketenagakerjaan Nomro 16 Tahun 2015 tentang Tata Cara Penggunaan Tenaga Kerja Asing.

Rencana Penggunaan Tenaga Kerja Asing (RPTKA) yang layak, baik itu dari segi alasan penggunaan tenaga kerja asing (TKA) dan telah melampirkan semua dokumen sebagaimana diisyaratkan berhak mendapat SK (Surat Keputusan) pengesahan Rencana Penggunaan Tenaga Kerja Asing (RPTKA). Adapun pengesahan Rencana Penggunaan Tenaga Kerja Asing (RPTKA) dapat dilakukan oleh Dirjen untuk pemberi kerja TKA yang mempekerjakan TKA sebanyak 50 (lima puluh) orang atau lebih dan Direktur untuk pemberi kerja TKA yang mempekerjakan TKA kurang dari 50 (lima puluh) orang. Sementara, surat Keputusan Pengesahan RPTKA memuat alasan penggunaan TKA, jabatan dan / atau kedudukan TKA, lokasi kerja TKA, upah / gaji TKA, jumlah TKA, jangka waktu penggunaan TKA, jumlah TKI yang ditunjuk sebagai TKI pendamping, dan jumlah TKI yang dipekerjakan.

Rencana Penggunaan Tenaga Kerja Asing (RPTKA) yang telah disahkan tadi diberikan untuk jangka waktu paling lama 5 (lima) tahun dan dapat di perpanjang untuk jangka waktu yang sama, dengan memperhatikan kondisi pasar kerja dalam negeri. Berikut ini merupakan permohonan perpanjangan RPTKA yang harus dilengkapi, meliputi alasan penggunaan TKA, formulir RPTKA yang sudah diisi, surat izin usaha dari instansi yang berwenang, akta dan keputusan pengesahan pendirian dan/atau perubahan dari instansi yang berwenang, bagan struktur organisasi perusahaan, rekomendasi jabatan yang akan diduduki oleh TKA dari instansi teknis sesuai dengan peraturan yang berlaku di Instansi teknis terkait, keterangan domisili perusahaan dari pemerintah daerah setempat, Nomor Pokok Wajib Pajak (NPWP) pemberi kerja TKA, surat penunjukan TKI pendamping dan rencana program pendampingan, dan surat persyaratan untuk melaksanakan pendidikan dan pelatihan kerja bagi TKI sesuai dengan kualifikasi jabatan yang diduduki oleh TKA, bukti wajib lapor ketenagakerjaan yang masih berlaku sesuai Undang-Undang Nomor 7 Tahun 1781.

Penggunaan tenaga kerja asing yang akan dipekerjakan di Indonesia maka harus memuat persyaratan tersebut dengan memperhatikan memperhatikan berbagai 
prosedur untuk mendapatkan rencana penggunaan tenaga kerja asing (RPTKA) yang didalamnya harus memuat keterangan-keterangan rencana penggunaan tenaga kerja asing yang antara lain disebutkan pada Pasal 36 ayat (2) Peraturan Menteri Ketenagakerjaan Nomor 35 Tahun 2015 tentang Perubahan Atas Peraturan Menteri Ketenagakerjaan Nomor 16 Tahun 2015 tentang Tata Cara Penggunaan Tenaga Kerja Asing. Karena rencana penggunaan tenaga kerja asing (RPTKA) merupakan dokumen awal yang harus dipersiapkan oleh pemberi kerja yang berisi rencana penggunaan tenaga kerja asing pada jabatan tertentu untuk jangka waktu tertentu dan harus mendapat pengesahan oleh menteri atau pejabat yang ditunjuk. Karena rencana penggunaan tenaga kerja asing (RPTKA) digunakan sebagai dasar yang bertujuan untuk mendapatkan izin mempekerjakan tenaga kerja (IMTA). ${ }^{6}$ Akan tetapi pada Pasal 36 ayat (3) menegaskan bahwa kewajiban dalam membuat rencana penggunaan tenaga kerja asing (RPTKA) untuk pemberi kerja yang akan mempekerjakan tenaga kerja asing di Indonesia dikecualikan khusus untuk pemberi kerja yang berupa instansi pemerintah, badan-badan instansi pemerintahan, badan-badan internasional dan perwakilan negara asing. Di dalam Pasal 44 disebutkan, pertama, pemberi kerja asing wajib menaati ketentuan mengenai jabatan dan standar kompetensi yang berlaku; dan kedua ketentuan mengenai jabatan dan standar kompetensi sebagaimana dimaksud dalam ayat (1) diatur dengan Keputusan Menteri.

Pada Pasal diatas mengenai jabatan dan standar kompetensi yang berlaku diatur lebih lanjut pada Peraturan Menteri Ketenagakerjaan Republik Indonesia Nomor 35 Tahun 2015 tentang Perubahan Atas Peraturan Menteri Ketenagakerjaan Nomor 16 Tahun 2015 tentang Tata Cara Penggunaan Tenaga Kerja Asing pada Pasal 36 ayat (1) bahwa tenaga kerja asing yang dipekerjakan oleh pemberi kerja tenaga kerja asing wajib memenuhi persyaratan yaitu memiliki pendidikan yang sesuai dengan syarat jabatan yang akan di duduki oleh tenaga kerja asing, memilki sertifikat kompetensi atau sertifikat pengalaman kerja sesuai dengan jabatan yang akan diduduki tenaga kerja asing paling kurang lima tahun, kemudian syarat pernyataan wajib mengalihkan keahliannya kepada TKI pendamping yang dibuktikan dengan laporan pelaksanaan pendidikan dan pelatihan, kemudian dari ketiga persyaratan tidak berlaku untuk jabatan anggota direksi, dewan komisaris atau anggota pembina, pengurus, dan pengawas. Kemudian pada Pasal 45 Undang-Undang Nomor 13 Tahun 2003 tentang Ketenagakerjaan bahwa, pertama, pemberi kerja asing tenaga kerja asing wajib menunjuk tenaga kerja warga negara Indonesia sebagai tenaga pendamping tenaga kerja asing yang dipekerjakan untuk alih teknologi dan alih keahlian dari tenaga kerja asing dan melaksanakan pendidikan dan pelatihan kerja bagi tenaga kerja Indonesia sebagaimana dimaksud pada huruf a yang sesuai dengan kualifikasi jabatan yang diduduki oleh tenaga kerja asing; kedua, ketentuan sebagaimana dimaksud dalam ayat (1) tidak berlaku bagi tenaga kerja asing yang menduduki jabatan direksi dan/atau komisaris.

6 Agushamidah, 2010, Dinamika e Kajian Teori Hukum Ketenagakerjaan Indonesia, Jakarta: Ghalia Indonesia, hlm. 113. 
Pasal 49 menegaskan bahwa tenaga kerja asing yang bekerja di Indonesia dilarang menduduki jabatan yang mengurusi personalia dan/atau jabatan-jabatan yang tertentu dimana jabatan-jabatan yang dilarang pada Pasal 49 Undang-Undang Nomor 13 Tahun 2003 tentang Ketenagakerjaan diatur lebih lanjut pada Peraturan Menteri Ketenagakerjaan Nomor 35 Tahun 2015 tentang Perubahan Atas Peraturan Menteri Ketenagakerjaan Nomor 16 Tahun 2015 tentang Tata Cara Penggunaan Tenaga Kerja Asing yang menegaskan bahwa jabatan-jabatan yang dilarang antara lain: jabatan anggota direksi, anggota dewan komisaris atau anggota pembina, anggota pengurus, anggota pengawas. Kemudian juga ditegaskan bahwa pemberi kerja yang mempekerjakan tenaga kerja asing wajib memulangkan tenaga kerja asing ke negeri asalnya setelah hubungan kerja dengan tenaga kerja asing telah berakhir masa kerja yang telah di perjanjikan. Kemudian pada Pasal 49 menegaskan mengenai penggunaan tenaga kerja asing serta pelaksanaan pendidikan dan pelatihan tenaga kerja pendamping diatur lebih lanjut pada keputusan menteri.

Surat keputusan pengesahan rencana penggunaan tenaga kerja asing (RPTKA) ${ }^{7}$ untuk lebih lanjut diatur pada Keputusan Menteri Ketenagakerjaan Nomor 35 Tahun 2015 tentang Perubahan Atas Peraturan Menteri Ketenagakerjaan Nomor 16 Tahun 2015 tentang Tata Cara Penggunaan Tenaga Kerja Asing di dalam Pasal 6, yang menegaskan bahwa pemberi kerja untuk mendapatkan rencana penggunaan tenaga kerja asing harus mulai dari mengajukan permohonan secara online kepada dirjen melalui direktur dengan mengunggah alasan penggunaan tenaga kerja asing, formulir rencana penggunaan tenaga kerja asing yang telah diisi, surat izin usaha dari instansi yang berwenang, akta dan keputusan pengesahan pendiriaan dan/atau perubahan dari instansi yang berwenang, bagan struktur organisasi perusahaan, rekomendasi jabatan yang akan diduduki oleh tenaga kerja asing dari instansi teknis sesuai dengan peraturan yang berlaku di instansi teknis terkait, keterangan domisili perusahaan dari pemerintah daerah setempat, Nomor Pokok Wajib Pajak (NPWP) pemberi kerja tenaga kerja asing, surat penunjukkan TKI pendampig dan rencana program pendampingan, dan surat pernyataan untuk melaksanakan pendidikan dan pelatihan kerja bagi TKI sesuai dengan kualifikasi jabatan yang di duduki oleh tenaga kerja asing, bukti wajib lapor ketenagakerjaan yang masih berlaku sesuai dengan Undang-Undang Nomor 7 Tahun 1981.

Rencana penggunaan tenaga kerja asing (RPTKA) yang telah disahkan tadi diberikan tadi diberikan untuk jangka waktu paling lama 5 (lima) tahun dan dapat diperpanjang untuk jangka waktu yang sama, dengan memperhatikan kondisi pasar kerja dalam negeri. Berikut ini merupakan permohonan perpanjangan rencana penggunaan tenaga kerja asing (RPTKA) yang harus dilengkapi meliputi laporan pelaksanaan pendidikan dan pelatihan serta surat keputusan rencana penggunaan tenaga kerja asing (RPTKA) yang akan diperpanjang. ${ }^{8}$

\footnotetext{
Ibid, hlm. 115 .

8 Ibid, hlm. 116.
} 
Izin mempekerjakan tenaga kerja asing atau IMTA merupakan langkah selanjutnya setelah pemberi kerja mendapat pengesahan rencana penggunaan tenaga kerja asing (RPTKA). ${ }^{9}$ Pengertian perizinan dilihat dari kamus istilah hukum, ijin merupakan sebagai perkenaan/izin dari pemerintah dimana mensyaratkan untuk perbuatan yang pada umumnya memerlukan pengawasan yang khusus, akan tetapi pada umumnya tidaklah dianggap sebagai hal-hal yang sama sekali tidak dikehendaki. Ateng Syafrudin seperti yang dikutip oleh Ridwan HR, mengatakan bahwa ijin bertujuan dan berarti menghilangkan halangan, hal yang dilarang menjadi boleh. ${ }^{10}$ Sementara Sjahran Basah, izin adalah perbuatan hukum administrasi negara bersegi satu yang mengaplikasikan peraturan dalam hal konkret berdasarkan persyaratan dan prosedur sebagaimana ditetapkan oleh ketentuan peraturan perudang-undangan. ${ }^{11}$

Izin penggunaan tenaga kerja asing atau IMTA merupakan langkah selanjutnya setelah pemberi kerja mendapat pengesahan Rencana Penggunaan Tenaga Kerja Asing (RPTKA). Mengenai IMTA diatur dalam Peraturan Menteri Ketenagakerjaan Nomor 35 Tahun 2015 Tentang Perubahan atas Peraturan Menteri Ketenagakerjaan Nomor 16 Tahun 2015 tentang Tata Cara Penggunaan Tenaga Kerja Asing.

Syarat syarat yang harus dipenuhi oleh TKA yaitu pertama, Memiliki pendidikan yang sesuai dengan syarat jabatan yang akan di duduki oleh TKA; kedua, memilki sertifikat kompetensi atau memiliki pengalaman kerja sesuai dengan jabatan yang akan diduduki TKA paling kurang 5 (lima) tahun; ketiga, surat pernyataan wajib mengalihkan keahliannya kepada TKI pendamping yang dibuktikan dengan laporan pelaksanaan pendidikan dan pelatihan; keempat, memiliki NPWP bagi TKA yang sudah bekerja lebih dari 6 (enam) bulan; kelima, memiliki bukti polis asuransi pada asuransi yang berbadan hukum indonesia; keenam, kepesertaan Jaminan Sosial Nasional bagi TKA yang bekerja lebih dari 6 (enam) bulan.

Guna mendukung iklim investasi, pemerintah mempermudah prosedur izin mempekerjakan tenaga kerja aing di Indonesia. Penyederhanaan prosedur dan waktu pengurusan izin tersebut telah dituangkan di Peraturan Menteri Ketenagakerjaan Nomor 35 Tahun 2015 tentang Perubahan Atas Peraturan Menteri Ketenagakerjaan Nomor 16 Tahun 2015 tentang Tata Cara Penggunaan Tenaga Kerja Asing. Jadi prinsip penggunaan tenaga kerja asing yang pertama Legal artinya setiap pemberi kerja yang mempekerjakan tenaga kerja asing harus memiliki izin tertulis dari menteri atau pejabat yang ditunjuk (Pasal 42 ayat (1) Undang-Undang Nomor 13 Tahun 2003, kedua sponsorship artinya pemberi kerja orang perorangan dilarang mempekerjakan tenaga kerja asing (Pasal 42 ayat (2) Undang-Undang Nomor 13 Tahun 2003), ketiga selective artinya tenaga kerja asing yang dipekerjakan dalam hubungan kerja untuk jabatan tertentu dan waktu tertentu (Pasal 42 ayat (4), dan terakhir security artinya penggunaan tenaga kerja asing harus sesuai dengan peraturan perundangan yang berlaku di Indonesia dan tidak membahayakan keamanan negara.

\footnotetext{
9 Ibid.

10 Ridwan HR, 2003, Hukum Administrasi Negara, Yogyakarta, UII Press, Cetakan Kedua, hlm.152

11 Ibid.
} 


\section{KEPASTIAN HUKUM REGULASI PENGGUNAAN TENAGA KERJA ASING}

Kepastian hukum secara normatif yaitu ketika suatu peraturan yang dibuat dan diundangkan secara pasti karena mengatur secara jelas dan logis. Jelas dalam artian tidak menimbukan keragu-raguan (multitafsir) dan logis dalam artian menjadi suatu sistem norma dengan norma lain sehingga tidak menimbulkan benturan atau menimbulkan konflik norma. Konflik norma yang ditimbulkan dari ketidakpastian aturan dapat berbentuk kontestasi norma, reduksi norma, atau distorsi norma. Menurut Sudikno Mertokusumo kepastian hukum adalah jaminan bahwa hukum dijalankan, bahwa yang berhak menurut hukum dapat memperoleh haknya dan bahwa putusan dapat dilaksanakan. Walaupun kepastian hukum erat kaitannya dengan keadilan, namun hukum tidak identik dengan keadilan. Hukum bersifat umum, mengikat setiap orang, bersifat menyamaratakan, sedangkan keadilan bersifat subyektif, individualistis, dan tidak menyamaratakan. ${ }^{12}$

Sudah umum bilamana kepastian hukum sudah menjadi bagian dari suatu hukum, hal ini lebih diutamakan untuk norma hukum tertulis, karenanya tanpa nilai kepastian akan kehilangan jati diri serta maknanya, karena tidak ada lagi dapat digunakan sebagai pedoman perilaku setiap orang. Kepastian sendiri hakikatnya merupakan tujuan utama dari hukum. Apabila dilihat secara historis banyak perbincangan yang telah dilakukan mengenai hukum semenjak Mntesquieu mengeluarkan gagasan mengenai pemisahan kekuasaan. Keteraturan masyarakat berkaitan erat dengan kepastian hukum dalam hukum karena keteraturan merupakan inti dari kepastian itu sendiri. Dari keteraturan akan menyebabkan seseorang hidup secara berkepastian dalam melakukan kegiatan yang diperlukan dalam kehidupan masyarakat. Menurut Sudikno Mertokusumo ${ }^{13}$ kepastian hukum merupakan sebuah jaminan bahwa hukum tersebut harus dijalankan dengan cara yang baik. Kepastian ukum menghendaki adanya upaya pengaturan hukum dalam perundang-undangan yang dibuat oleh pihak yang berwenang, sehingga aturan-aturan itu memiliki aspek yuridis yang dapat menjamin adanya kepastian bahwa hukum berfungsi sebagai suatu peraturan yang harus ditaati.

Lon Fuller dalam bukunya the morality of law mengajukan 8 (delapan) asas yang harus dipenuhi oleh hukum, yang apabila tidak terpenuhi, maka hukum akan gagal untuk disebut sebagai hukum, atau dengan kata lain harus terdapat kepastian hukum. Kedelapan asas tesebut adalah pertama, suatu sistem hukum yang terdiri dari peraturanperaturan, tidak berdasarkan putusan-putusan sesaat untuk hal-hal tertentu; kedua, peraturan tersebut diumumkan ke publik; ketiga, tidak berlaku surut, karena akan merusak integritas sistem; keempat, dibuat dalam rumusan yang dimegerti oleh umum; kelima, tidak boleh ada peraturan yang saling bertentangan; keenam, tidak boleh

\footnotetext{
12 Sudikno Mertokusumo, 2007, Mengenal Hukum Suatu Pengantar, ed ke-3 cet.ke-1. Yogyakarta: Liberty, hlm. 13.

13 Sudikno Mertokusumo, 2009, Penemuan Hukum, Yogyakarta: Liberty, hlm. 21.
} 
menuntut suatu tindakan yang melebihi apa yang bisa dilakukan; ketujuh, harus ada kesesuaian antara peraturan dan pelaksanaan sehari-hari.

Pendapat Lon Fuller diatas dapat dikatakan bahwa harus ada kepastian antara peraturan dan pelaksanaannya dengan demikian sudah memasuki ranah aksi, perilaku, dan faktor-faktor yang mempengaruhi bagaimana hukum positif. Asas kepastian hukum merupakan asas dalam negara hukum yang mengutamakan landasan peraturan perundang-undangan, kepatutan, dan keadilan dalam setiap kebijakan penyelenggaraan negara. Esensi negara hukum tedapat asas legalitas dan kepastian hukum. Asas legalitas di ilhami atas pemikiran untuk membatasi kekuasaan penguasa dengan bersaranakan hukum pembatasan ini menjadi penting untuk mengimbangi kewenangan yang diberikan kepada pemerintah untuk ikut serta/campur tangan dalam kehidupan pribadi. Pembatasan ini bertujuan untuk mencegah penguasa melanggar hak-hak individu, sedangkan sarana yang membatasi campur tangan negara pada kehidupan individu diatur dalam Undang-Undang. ${ }^{14}$ Undang-Undang merupakan landasan keabsahan campur tangan negara dalam kehidupan pribadi, diluar kewenangan yang diberikan oleh Undang-Undang dianggap sebagai suatu pelanggaran dalam kehidupan pribadi. Selanjutnya tujuan utama dalam asas legalitas adalah menciptakan kepastian hukum agar pemerintah tidak bertindak sewenang-wenang. Asas kepastian hukum merupakan asas yang mengutamakan landasan Peraturan Perundang-Undangan, kepatutan, keadilan, dalam setiap kebijakan penyelenggara negara. Sedangkan asas legalitas merupakan asas yang selalu dijunjung tinggi oleh setiap negara yang menyatakan dirinya sebagai negara hukum. ${ }^{15}$

Beberapa Peraturan Perundang-Undangan telah ditetapkan yang mengatur aspek-aspek dasar dan bentuk peraturan yang mengatur tujuan penggunaan tenaga kerja asing secara selektid dengan tetap memprioritaskan TKI. Peraturan yang dimaksud adalah Undang-Undang Nomor 13 Tahun 2003 tentang Ketenagakerjaan, Peraturan Presiden Republik Indonesia Nomor 72 Tahun 2014 tentang Penggunaan Tenaga Kerja Asing serta Pelaksanaan Pendidikan dan Pelatihan Tenaga Kerja Pendamping, Peraturan Menteri Ketenagakerjaan Nomor 16 Tahun 2015 tentang Tata Cara Penggunaan Tenaga Kerja Asing serta Peraturan Menteri Ketenagakerjaan Nomor 35 Tahun 2015 tentang Perubahan Atas Peraturan Menteri Ketenagakerjaan Nomor 16 Tahun 2015 tentang Tata Cara Penggunaan Tenaga Kerja Asing.

Undang-Undang Nomor 13 Tahun 2003 tidak mengatur tenaga kerja asing secara terperinci, sehingga sejumlah pengaturan tersebut masih didelegasikan dengan aturanaturan pelaksana. Maka pengaturan tenaga kerja asing menjadi sangat fleksibel yang dampaknya mudah dilakukan perubahan aturan-aturan tersebut. Salah satunya adalah aturan-aturan yang terdapat pada Peraturan Menteri Ketenagakerjaan tahun 2015, pada peraturan ini telah mengalami perubahan sebanyak 2 kali yaitu Peraturan Menteri Ketenagakerjaan Nomor 16 Tahun 2015 telah diubah oleh Peraturan Menteri

14 Hotma P. Sibue, 2010, Asas Negara Hukum, Peraturan Kebijakan e Asas-Asas Umum Pemerintahan yang Baik, Jakarta: Erlangga, hlm. 32.

15 Indroharto, 2004, Usaha Memahami Undang-Undang tentang Peradilan Tata Usaha Negara, Jakarta: Pustaka Sinar Harapan, hlm. 83. 
Ketenagakerjaan Nomor 35 Tahun 2015. Salah satunya adalah penghapusan kewajiban bagi pemberi kerja untuk menyerap sekurang-kurangnya 10 orang TKI apabila mempekerjakan 1 TKA serta tidak ada lagi ketentuan WNA untuk dapat berbahasa Indonesia. Artinya bahasa Indonesia bukan suatu keharusan. Dengan demikian akan memberikan dampak negatif dan dampak positif seperti banyaknya tenaga kerja asing yang berbondong-bondong ke Indonesia tidak belajar berbahasa Indonesia, tidak terhambatnya masuk modal asing, sedangkan dampat negatifnya adalah menghambat alih tehnologi dari tenaga kerja asing kepada TKI pendamping. Persyaratan lain yang banyak dilanggar dalam praktiknya seperti jabatan atau bentuk pekerjaan yang dapat dilakukan oleh tenaga kerja asing.

Kemudian juga harus memperhatikan persyaratan-persyaratan yang harus dipenuhi oleh tenaga kerja asing di Indonesia antara lain memiliki sertifikat kompetensi atau sertifikat pengalaman kerja sesuai dengan jabatan yang diduduki tenaga kerja asing paling kurang 5 (lima) tahun, membuat surat pernyataan wajib mengalihkan keahliannya kepada TKI pendamping yang dibuktikan dengan laporan pelaksanaan pendidikan dan pelatihan. Izin penggunaan tenaga kerja asing merupakan langkah selanjutnya setelah pemberi kerja mendapatkan rencana penggunaan tenaga kerja asing (RPTKA). ${ }^{16}$

Jika ditinjau dari pembentukkan peraturan perundang-undangan harus mempunyai dasar keabsahan baik secara formil maupun secara materill, dasar keabsahan yang bersifat forml berkaitan mengenai tata cara prosedur pembentukan peraturan perundang-undangan, sedangkan dasar keabsahan yang bersifat materiil berkaitan mengenai materi atau subtansi (isi) dalam suatu peraturan perundangundangan. $^{17}$

Menurut Bagir Manan kaitannyia mengenai syarat-syarat pembentukkan peraturan perundang-undangan dalam keberlakuan yuridis dari kaidah hukum yaitu, pertama, keharusan adanya kewenangan dari pembuat peraturan perundang-undangan. Ketentuan ini menyatakan bahwa setiap peraturan perundang-undangan harus dibuat oleh pejabat atau badan yang memiliki kewenangan dalam membuat peraturan perundang-undangan; kedua, keharusan mengenai adanya kesesuaian jenis atau bentuk peraturan perundang-undangan dengan materi yang telah diatur, terutama kalau diperintah oleh peraturan perundang-undangan yang mempunyai tingkatan, lebih tinggi, dan/atau sederajat. Ketidaksesuaian mengenai bentuk ini menjadi suatu alasan untuk membatalkan peraturan perundang-undangan tersebut; ketiga, keharusan dalam hal mengikuti tata cara yang telah ditentukan. Apabila tata cara tersebut ditaati atau diikuti, maka peraturan perundang-undangan tersebut batal demi hukum atau dapat dikatakan tidak mempunyai kekuatan hukum yang mengikat; keempat, keharusan terhadap peraturan yang lebih rendah tidak boleh sampai bertentangan dengan peraturan yang lebih tinggi tingkatannya, karena suatu peraturan perundang-undangan

\footnotetext{
16 Agushamidah, supra note 6, hlm. 116.

17 Bayu Dwi Anggono, Perkembangan Pembentukan Undang-Undang Di Indonesia, Konstitusi Pers, Jakarta, 2014 hlm. 189.
} 
tidak dapat mengandung kaidah yang bertentangan dengan konstitusi atau UUD 1945. ${ }^{18}$

Berdasarkan uraian diatas pada angka 4 dalam syarat-syarat pembentukan peraturan perundang-undangan, pada angka 4 menyatakan bahwa dalam peraturan perundang-undangan terdapat suatu keharusan dimana norma atau peraturan yang lebih rendah tidak boleh sampai bertentangan dengan norma yang lebih tinggi terutama sampai bertentangan dengan norma dasar yaitu pada UUD 1945. Maka permasalahan hukum yakni dari pengaturan tersebut sebagaimana telah dilakukan perubahan terhadap penggunaan tenaga kerja asing yang sebelumnya Peraturan Menteri Ketenagakerjaan Nomor 16 Tahun 2015 Tentang Tata Cara Penggunaan Tenaga Kerja Asing telah mencantumkan berbagai regulasi dimana membebaskan dan mengetatkan penggunaan tenaga kerja asing Pada Pasal 3 yang berbunyi "Pemberi kerja tenaga kerja asing (TKA) yang mempekerjakan 1 (satu) orang TKA harus dapat menyerap TKI sekurang-kurangnya 10 (sepuluh) orang pada perusahaan pemberi kerja TKA", selain itu pada Pasal 36 Ayat (1) yang berbunyi " Tenaga Kerja Asing (TKA) yang dipekerjakan wajib memiliki pendidikan yang sesuai dengan jabatan yang dimiliki dan memiliki sertifikat kompetensi atau pengalaman sekurang-kurangnya 5 (lima) tahun" . dengan kata lain, TKA harus benar-benar kompeten dibidang tersebut agar dapat bekerja di Indonesia. Setiap TKA harus memilki seorang pendamping TKI alih bahasa dan transfer tehnologi.

Akan tetapi kebijakan Peraturan Menteri Ketenakerjaan telah direvisi oleh Peraturan Menteri ketenagakerjaan Nomor 35 Tahun 2015 tentang Perubahan Atas Peraturan Menteri Ketenagakerjaan Nomor 16 Tahun 2015 tentang Tata cara Penggunaan Tenaga Kerja Asing. Sehingga dalam menghadapi perdagangan bebas, maka diperlukan pengaturan terhadap ketenagakerjaan yang mengacu kepada regulasi tentang penggunaan tenaga kerja asing. Jadi dapat disimpulkan bahwa Peraturan Menteri Ketenagakerjaan Nomor 35 Tahun 2015 tentang Peraturan Menteri Ketenagakerjaan Nomor 35 Tahun 2015 tentang Tata Cara Penggunaan Tenaga Kerja Asing tidak berkepastian hukum melihat beberapa Pasal yang mengetatkan dan membebaskan penggunaan tenaga kerja asing pada Pasal 3, Pasal 36 ayat (1) \& Pasal 40 ayat (2) Peraturan Menteri Ketenagakerjaan Nomor 16 Tahun 2015 diatur bahwa DKPTKA yang dibayarkan harus dikonversi ke Rupiah. Permenaker 35/2015 menghapuskan ketentuan ini. Penghapusan ini bertentangan dengan Undang-Undang Nomor 7 Tahun 2011 tentang Mata Uang ("UU 7/201l”). Penghapusan Pasal ini artinya menghapuskan aturan mengenai rasio jumlah TKA dengan tenaga kerja lokal.

Penghapusan di atas dikhawatirkan menghilangkan kesempatan terjadinya alih pengetahuan dan alih teknologi dari TKA ke tenaga kerja lokal. Meskipun dalam Pasal 65 Permenaker 16/2015 disebutkan bahwa perusahaan pemberi kerja dapat menugaskan TKA untuk melakukan alih teknologi dan keahlian di lembaga pendidikan dan pelatihan, namun bisa jadi hal ini tidak dilaksanakan jika tidak diwajibkan secara jelas dalam peraturan perundang-undangan. Apalagi saat ini Keputusan Direktorat Jenderal

18 Ibid, hlm. 190. 
yang mengatur mengenai pendampingan TKA oleh tenaga kerja lokal untuk alih teknologi dan keahlian belum diterbitkan sebagaimana disebutkan dalam Pasal 66A Permenaker 35/2015. Di sisi yang lain, penghapusan rasio ini memberikan kemudahan bagi perusahaan yang berbisnis di Indonesia untuk memperkerjakan TKA secara lebih murah karena tidak perlu memperkerjakan lebih banyak tenaga kerja lokal dan tidak adanya kewajiban melakukan pelatihan pada tenaga kerja lokal.

\section{KESIMPULAN}

Mencermati substansi ketentuan perundang-undangan sebagaimana diuraikan diatas, maka dapat dipahami bahwa pengaturan penggunaan tenaga kerja asing di Indonsia dalam proses penggunaan tenaga kerja asing di Indonesia harus melihat peraturan yang mengatur penggunaan tenaga kerja asing yang diatur dalam Undang-Undang Nomor 13 tahun 2014 tentang Ketenagakerjaan pada BAB VI Pasal 42-49 mengenai penggunaan tenaga kerja asing dan diatur lebih lanjut pada Peraturan Menteri Ketenagakerjaan Nomor 35 Tahun 2015 tentang Perubahan Atas Peraturan Menteri Ketenagakerjaan Nomor 16 Tahun 2015 tentang Tata Cara Penggunaan tenaga kerja asing khususnya pada Pasal 36 ayat (1). Akan tetapi pengaturan penggunaan tenaga kerja asing Peraturan Menteri Ketenagakerjaan Nomor 35 Tahun 2015 tentang Peraturan Menteri Ketenagakerjaan Nomor 35 Tahun 2015 tentang Tata Cara Penggunaan Tenaga Kerja Asing tidak berkepastian hukum melihat beberapa Pasal yang mengetatkan dan membebaskan penggunaan tenaga kerja asing pada Pasal 3, Pasal 36 ayat (1) \& Pasal 40 ayat (2) Peraturan Menteri Ketenagakerjaan Nomor 16 Tahun 2015 diatur bahwa DKPTKA yang dibayarkan harus dikonversi ke Rupiah. Permenaker 35/2015 menghapuskan ketentuan ini. Penghapusan ini bertentangan dengan Undang-Undang Nomor 7 Tahun 2011 tentang Mata Uang ("UU 7/2011").

\section{DAFTAR PUSTAKA}

Aries Harianto, 2016, Hukum Ketenagakerjaan Makna Kesusilaan dalam Perjanjian Kerja, Yogyakarta: LakBang PRESSindo.

Bayu Dwi Anggono, Perkembangan Pembentukan Undang-Undang Di Indonesia, Konstitusi Pers, Jakarta, 2014

Agusmidah, 2010, Dinamika \& Kajian Teori Hukum Ketenagakerjaan Indonesia, Jakarta: Ghalia Indonesia.

Agusmidah, 2011, Dilematika Hukum Ketenagakerjaan Tinjauan Politik Hukum, Jakarta: PT. Sofmedia.

Budiono, Abdul Rachat, 1995, Hukum Perburuhan Di Indonesia, Jakarta: PT. Rajagrafindo Persada.

H.S Syarif, 1996, Pedoman Penggunaan tenaga kerja asing di Indonesia, Jakarta: Sinar Grafika.

HR Abdussalam, 2008, Hukum Ketenagakerjaan, Jakarta: Restu agung 
401 | Kepastian Hukum Pengaturan Penggunaan Tenaga Kerja Asing di Indonesia

Hotma P. Sibuea, 2010, Asas Negara Hukum, Peraturan Kebijakan e Asas-Asas Umum Pemerintahan yang Baik, Jakarta: Erlangga

Indroharto, 2004, Usaha Memahami Undang-Undang tentang Peradilan Tata Usaha Negara, Jakarta: Pustaka Sinar Harapan.

Ridwan HR, 2003, Hukum Administrasi Negara, UII Press, Yogyakarta: Cetakan Kedua, Yogyakarta.

Sudikno Mertokusumo, 2007, Mengenal Hukum Suatu Pengantar, ed ke-3 cet.ke-1. Yogyakarta: liberty.

Sudikno Mertokusumo, Penemuan Hukum, Yogyakarta: Liberty, 2009 
402 | LENTERA HUKUM

This page is intentionally left blank 